cemoti $\begin{aligned} & \text { Cahiers d'études sur la Méditerranée } \\ & \text { orientale et le monde turco-iranien }\end{aligned}$

19 | 1995

Laïcité(s) en France et en Turquie

\title{
Les socialistes français et la laïcité
}

Jean-William DEREYMEZ

\section{(2) OpenEdition}

Journals

Édition électronique

URL : http://journals.openedition.org/cemoti/218

DOI : $10.4000 /$ cemoti. 218

ISSN : $1777-5396$

Éditeur

AFEMOTI

Édition imprimée

Date de publication : 1 janvier 1995

Pagination :

235_253

ISSN : 0764-9878

Référence électronique

Jean-William DEREYMEZ, "Les socialistes français et la laïcité », Cahiers d'études sur la Méditerranée orientale et le monde turco-iranien [En ligne], 19 | 1995, mis en ligne le, consulté le 08 septembre 2020 URL : http://journals.openedition.org/cemoti/218; DOI : https://doi.org/10.4000/cemoti.218

Ce document a été généré automatiquement le 8 septembre 2020

Tous droits réservés 


\section{Les socialistes français et la laïcité}

\section{Jean-William DEREYMEZ}

\section{RÉSUMÉS}

La position des socialistes français concernant la laïcité est beaucoup plus complexe qu'on ne le pense, d'abord en raison de la définition du terme même de laïcité qui diffère selon les différents courants du Parti socialiste, puis en raison des mutations sociales de cette fin de siècle et notamment du développement de religions jusque là minoritaires. Le débat actuel oppose essentiellement les tenants de la laïcité traditionnelle à ceux d'une laïcité "plurielle" épousant la diversité culturelle du pays. 